\title{
Peculiarities of acousto-optic diffraction at circularly polarized acoustic waves. Determination of elasto-optic coefficients coupled with shear waves. Errata
}

\author{
Kostyrko M., Orykhivskyi I., Skab I. and Vlokh R. \\ O. G. Vlokh Institute of Physical Optics, 23 Dragomanov Street, 79005 Lviv, \\ Ukraine vlokh@ifo.lviv.ua
}

Received: 29.12 .2020

\begin{abstract}
We have found some errors in our recent analysis of acousto-optic diffraction on the circularly polarized acoustic waves performed in Ref. [Kostyrko M., Orykhivskyi I., Skab I. and Vlokh R. 2020. Peculiarities of acousto-optic diffraction at circularly polarized acoustic waves. Determination of elasto-optic coefficients coupled with shear waves. Ukr. J. Phys. Opt. 21: 201-206].
\end{abstract}

Keywords: circularly polarized acoustic waves, acousto-optic diffraction, effective elasto-optic coefficients

UDC: $535.421+535.551+534.27$

We have found some errors in our recent analysis of acousto-optic diffraction on the circularly polarized acoustic waves performed in Ref. [1].

Abstract should be rewritten as follows:

"We develop a new approach for determining some of elasto-optic coefficients $\left(p_{i j}\right.$ with $i=1 \ldots 6$ and $j=4,5)$ basing on Dixon-Cohen method and acousto-optic diffraction at circularly polarized acoustic waves. Particular cases of crystals that belong to trigonal system and some symmetry groups of tetragonal and hexagonal systems are analyzed. We find that the effective elastooptic coefficients are the same for the alternative cases of diffractions at either right- or left-handed circularly polarized acoustic waves that propagate along $Z$ axis in crystals. One can determine in this way the combination of coefficients $p_{44}$ and $p_{45}$ at the anisotropic diffraction in the crystals belonging to point symmetry groups $4,4 / \mathrm{m}, \overline{4}, 6,6 / \mathrm{m}$ and $\overline{6}$. For the crystals belonging to symmetry groups $32,3 \mathrm{~m}$ and $\overline{3} \mathrm{~m}$, it is possible to determine the coefficients $p_{14}$ and $p_{44}$ respectively at the isotropic and anisotropic diffractions. Finally, for the crystals described by the groups 3 and $\overline{3}$, one can determine the combination of four coefficients $p_{44}, p_{45}, p_{25}$ and $p_{14}$ following from the anisotropic diffraction data and the two coefficients $p_{14}$ and $p_{25}$ following from the isotropic-diffraction data."

The sentence below Eq. (5) should be rewritten as

“After averaging $\left\langle\sin ^{2} \delta\right\rangle=\left\langle\cos ^{2} \delta\right\rangle=1 / 2$, one gets the EEC equal to $p_{e f f}=\frac{1}{2} p_{44}$, since the relations $p_{45}, p_{64}, p_{65}=0$ hold true. Under the same diffraction conditions, we still have the same EEC for the case of LH AW."

The sentence below Eq. (6) should be rewritten as

"Since we have $p_{55}=p_{44}$, the EEC is equal to $p_{\text {eff }}=\frac{1}{2} p_{44}$. The EEC obtained for the alternative case of diffraction at the LH AW is equal to $p_{e f f}=\frac{1}{2} p_{44}$, i.e. the EEC remains the 
same. Hence, the EECs are the same for the $X Z$ and $Y Z$ interaction planes in $\mathrm{TeO}_{2}$. In addition, these parameters are invariant under changing sign of the circular AW."

Eq. (7) should be written as

$$
E_{3}=\Delta B_{32} D_{2}=\left(p_{44} e_{4}^{R H}+p_{45} e_{5}^{R H}\right) D_{2}=\left(p_{44} e_{0} \sin \delta-p_{45} \mathrm{e}_{0} \cos \delta\right) D_{2}
$$

Eq. (8) and the sentence immediately below it should be rewritten as

$$
E_{3}=\Delta B_{32} D_{2}=\left(p_{44} e_{4}^{R H}+p_{45} e_{5}^{R H}\right) D_{2}=\left(p_{44} e_{0} \sin \delta+p_{45} \mathrm{e}_{0} \cos \delta\right) D_{2} .
$$

Then the EEC is equal to $p_{\text {eff }}=\frac{1}{2} \sqrt{p_{44}^{2}+p_{45}^{2}}$ in the first and in the second cases.

Eq. (9) and the sentence immediately below it should be rewritten as

$$
E_{2}=\Delta B_{22} D_{2}=\left(p_{24} e_{4}^{R H}+p_{25} e_{5}^{R H}\right) D_{2}=-p_{14} e_{0} \sin \delta D_{2}, p_{e f f}=\frac{1}{2} p_{14} .
$$

The EEC remains the same when the isotropic interaction inside the $Y Z$ plane occurs or when the optical wave diffracts at the LH AW. Then one can determine the elasto-optic coefficient $p_{14}$.

The sentences below Eq. (9) should be rewritten as

"Then the EEC is defined as $p_{\text {eff }}=\frac{1}{2}\left(p_{14}^{2} \sin ^{2} \varphi+p_{44}^{2} \cos ^{2} \varphi\right)^{1 / 2}$, where $\varphi$ is the angle between the $X$ (or $Y$ ) axis and the wave vector of diffracted optical wave. Having determined the $p_{14}$ coefficient value in the isotropic diffraction study, one can also found the $p_{44}$ coefficient.

Finally, we consider the crystals that belong to the point symmetry groups 3 and $\overline{3}$. Let the isotropic interaction between the ordinary optical waves take place inside the $X Z$ and $Y Z$ planes. The EEC calculated for the cases of diffractions at the RH and LH AWs read as

$$
p_{\text {eff }}=\frac{1}{2} \sqrt{p_{14}^{2}+p_{25}^{2}} .
$$

This fact enables one to determine the combination of elasto-optic coefficients $p_{14}$ and $p_{25}$. On the other hand, the EEC is equal to zero when the extraordinary optical waves interact with each other and with the circular AWs.

The EEC for the case of anisotropic interaction inside the $X Z$ and $Y Z$ planes and diffraction at the RH and LH AWs is as follows:

$$
p_{\text {eff }}=\frac{\sqrt{2}}{2} \sqrt{\left(p_{44}^{2}+p_{45}^{2}\right) \cos ^{2} \varphi+\left(p_{25}^{2}+p_{14}^{2}\right) \sin ^{2} \varphi} .
$$

As a consequence, one can determine the combination of four coefficients $p_{44}, p_{45}, p_{25}$ and $p_{14}$."

Eqs. (12)-(14) and the discussion that follows these equations should be removed as erroneous.

Conclusion should be rewritten as follows:

"Issuing from the results of the present work, one can conclude that the AO diffraction at the circular AWs can be considered as an additional approach, which is useful when determining the elasto-optic coefficients via the Dixon-Cohen technique. Using this approach, one can find combinations of some of the elasto-optic coefficients ( $p_{i j}$ with $i=1 \ldots 6$ and $\left.j=4,5\right)$. In particular, one can measure a combination of coefficients $p_{44}$ and $p_{45}$ under conditions of anisotropic diffraction in the crystals belonging to the symmetry groups $4,4 / \mathrm{m}, \overline{4}, 6,6 / \mathrm{m}$ and $\overline{6}$. For the crystals that belong to the trigonal symmetries $32,3 \mathrm{~m}$ and $\overline{3} \mathrm{~m}$, it is possible to find the 
coefficients $p_{14}$ and $p_{44}$ respectively at the isotropic and anisotropic diffractions. For the crystals described by the groups 3 and $\overline{3}$, one can find combination of the four coefficients $p_{44}, p_{45}, p_{25}$ and $p_{14}$, using the studies of anisotropic diffraction. Finally, a combination of coefficients $p_{14}$ and $p_{25}$ for the same crystals can be evaluated following from the isotropic diffraction data. It is also worth noting that the EECs are defined by the same relationships for the cases of diffraction either at the RH AW or at the LH AW."

The Abstract in Ukrainian should be rewritten as

"Розроблено новий підхід до визначення деяких із еластооптичних коефіиієнтів ( $p_{i j}$ iз $i=1 \ldots 6$ mа $j=4$, 5) на основі методу Діксона-Коена та акустооптичної дифракиії на циркулярно поляризованих акустичних хвилях. Проаналізовано конкретні випадки кристалів, щьо належать до тригональної системи і деяких груп симетрії тетрагональної та гексагональної систем. Виявлено, що ефективні еластооптичні коефіцієнти $\epsilon$ однаковими для альтернативних випадків дифракції на правих або лівих акустичних хвилях, які поширюються вздовж осі $Z$ у кристалах. Так можна визначити комбінацію коефіцієнтів $p_{44}$ i $p_{45}$ при анізотропній дифракції в кристалах, щуо належать до точкових груп симетрії 4, 4/m, $\overline{4}, 6,6 / m i \overline{6}$. Для кристалів, що належсать до груп симетрії $32,3 m i$ $\overline{3} m$, можна знайти коефіџієнти $p_{14} i p_{44}$ відповідно при ізотропній $i$ анізотропній дифракції. Нарешті, для кристалів, що описуються групами $3 i \overline{3}$, можна визначити комбінацію чотирьох коефіцієнтів $p_{44}, p_{45}, p_{25}$ і $p_{14}$ на підставі даних для анізотропної дифракиії і двох коефіиієнти $p_{14}$ і р 25 на підставі даних для ізотропної дифракції.”

\section{Reference}

1.Kostyrko M., Orykhivskyi I., Skab I., and Vlokh R. 2020. Peculiarities of acousto-optic diffraction at circularly polarized acoustic waves. Determination of elasto-optic coefficients coupled with shear waves. Ukr. J. Phys. Opt. 21: 201-206.

Kostyrko M., Orykhivskyi I., Skab I. and Vlokh R. 2021 Peculiarities of acousto-optic diffraction at circularly polarized acoustic waves. Determination of elasto-optic coefficients coupled with shear waves. Errata. Ukr.J.Phys.Opt. 22: 50 - 52. doi: 10.3116/16091833/22/1/50/2021 